Харалампије Поленаковић

\title{
УТИЦАЈ ВУКОВЕ РЕФОРМЕ НА ЈЕЗИК И ПРАВОПИС У МАКЕДОНИЈИ
}

Почеци нове македонске књижевности, писане на живим народним говорима, падају управо у годину када је Вук, у Бечу, објавио своју "Писменииу сербског језика по говору простога народа написану" и Малу простонароднју славено-сербску пјеснарииу". Те, 1814. године, у Будиму, „Писмени кралев, свеучилишта унгарскаго” објављене су и прве две књиге најстаријег члана прве књижевне генерације нове македонске књижевности, Јоакима Крчовског. Прва књижица „Слово исказаное заради умирание” носи наслов прве беседе, а друга беседа је „Слово заради свјатое исповедание на сички христијани, на мужи и жени”. Обе беседе су дате на 30 страна мале осмине. Књижица је штампана адеспотно. На основу језика, утврђено је ауторство књижице. Исте године, на истом месту, и истим језиком, једним источномакедонским говором, са лексичким примесама и из других македонских говора, објављена је друга књижица Јоакима Крчковског, тачније „хаџи Јоакима”, како се даје његово име на насловној страни књижице „Повест ради страшнаго и втораго пришествија Христова”. Уз ово „Повест” додао је и „Слово второе свјатого пророка Данила". Укупно 46 страна. По својој садржини дело припада средњевековној, црквеној књижевности. Међутим, по живом народном говору ово дело, као и прво, значе почетак нове македонске књижевности, одмах да додам веома, веома скроман.

Сам аутор Крчовски коректно признаје да је друга његова књижица „собранаја от различних свјатих писанија” и да је преведена на простјејши језик Болгарски”. Разуме се да у овом случају није реч о бугарском језику, него овде се ради о простонародном језику, за разлику од црквенословенског. 
Раније сам, у радовима објављеним пре двадесетак година (Странииц од македонската књижевност, 1952, 1969), а нарочито у онима који су настали и објављени у време прославе стогодишњице смрти Вука Караџића (у 4 књизи Анала Филолошког факултета у Београду, у Споменици Вук Караџић, издање Вукова и Доситејева музеја, у Раду конгреса фолклориста Југославије, 1964) истакао факат да је Вук у своме „Додатку к санктпетербурским сравнитетним рјечницима свију језика и нарјечија, с особитим огледима бугарског језика" $(1821,1822)$ имао прилике да каже своје мишљење о језику у делима Јоакима Крчовског, конкретно о језику најкрупнијег дела Крчовског: „Различна поучителна наставленија”. (Будим, 1819). У поговору свога „Додатка...” Вук је споменуо и два дела Јоакима Крчовског „Митарства”, Будим, 1817, и „Различна поучителна наставнија". За језик последњег дела Крчовског, Караџић је писао: „Ова је књига писана токорсе Бугарским језиком, али управо нити је Бугарски, ни Руски, ни Славенски, него бесправилна смјеса из ова сва три језика". Вук је овако могао оценити језик главне књиге Крчовског, јер се језик Крчовског, иако је у себи имао македонску основу, састојао и од бројних осталих македонских дијалеката, и лексичких и речничких одлика језика осталих словенских балканских народа, поред оних из турског језика. Тако је изгледао у својим почецима још неоформљени македонски књижевни језик.

У једном свом раду, утврђујући извор четвртог дела Јоакима Крчовског, „Чудеса пресвјатија Богородищи” (Будим, 1817) - дело српског популарног писца Викентија Ракића, могао сам констатовати и велики утицај српског језика у македонском преводу овог дела.

Када сам се задржао у почетку свога реферата на случајној подударности појаве првих дела нове македонске књижевности и оних двају Вука Караџића из 1814, није ми била намера да утврдим неку конкретну везу између Вука и Крчовског, иако је први знао за другог, а други је могао знати за првог.

Почињући са објављивањем својих дела на живом, народном језику, Крчовски је одговарао захтеву свога времена, свакако гледајући да је и у српској књижевности, а пре Вука, све више у употреби био народни језик.

Други члан прве књижевне генерације у новој македонској књижевности, Кирил Тетоец Пејчиновић (1845), својим делима је подржао напор Јоакима Крчовског на увођењу народног језика у штампана дела. Иако свештено лице и некадашњи хиландарски монах, те као такав и 
настављач средњовековне књижевности и старог словенског језика, Пејчиновић је користићи диглосију, и уводећи живу народну реч, нарочито у оне партије својих књига које је наменио широком читалачком кругу, закорачио крупним кораком у ново време. О томе су сведочанство бројни његови записи и натписи, као и стиховани епитаф - сви писани у току педесетак година на народном језику, те његова дела „Огледало” (Будим, 1816), „Житије кюаза Лазара” (1818, остало у рукопису), и „Утјешеније грјешним" (Солун, 1840). Прво и последње дело, поред тога што садрже и текстове писане на црквенословенском језику (разне молитве), у основи - а то су беседе - писане су на скопско-тетовском дијалекту. Пејчиновић се за своја дела користио српским изворима; то изричито сам он истиче, када говори о „Житију кюаза Лазара”, које је у целини написао на народном језику.

Весма агилан, у једном свом запису, остављајући податке и о томе да будно прати и политичке догађаје у Београдском пашалуку (Први устанак), Пејчиновић је ступио у преписку са кнезом Милошем, када је дознао да се у Србији основала штампарија. Послао је кнезу рукопис свог „Утјешенија грјешним” и потребан новац, да се дело штампа у Србији. Међутим, митрополијска цензура није се са тим сложила, и Пејчиновић је добио свој рукопис назад.

И трећи члан прве књижевне генерације у новој македонској књижевности, штампар Теодосије Синаитски, ишао је укорак са својим временом: штампао је дела на разним македонским говорима.

Теодосије Синаитски је родом из Дојрана. Извесно време је био монах у манастиру св. Катарине на Синају (отуда: Синаитски). Крајем треће деценије XIX века био је свештеник у цркви светог Мине у Солуну, a 1837-1838. године основао је у Солуну прву македонску штампарију, која је, уз разне перипетије и пожаре, до 1841. објавила пет дела на македонском говорима.

За наше тренутно интересовање важно је задржати се на последњој књизи Кирила Пејчиновића, на „Утјешенију грјешним”, која је као четврта по реду књига штампана у Солунској штампарији Синаитског, 1840. године.

Споменуо сам нешто из историје свог дела Кирила Пејчиновића, коју смо реконструисали пок. Академик Колендић и ја, на основу архивских докумената $(1948,1951)$. 
Рукопис свога дела „Утјешеније грјешним” Пејчиновић је неколико година држао код себе, у манастиру Лешку, код Тетова. Малочас сам рекао да је ова Пејчиновићева књига објављена код Синаитског 1840. Како је дошло до тога да се Кирилово дело штампа код Синаитског, изнео је штампар Теодосије у предговору Пејчиновићевог дела. Овај предговор је једини сачувани књижевни текст Теодосија синаитског, али по својој прокламацији у корист народног језика, он представља веома важан докуменат у историји македонског језика.

У неколико речи ево садржине Теодосијевог предговора. Кирил (Пејчиновић) је велики и заслужни син свога народа. Он је помогао обнову Теодосијеве штампарије, која је 1839. или 1840. изгорела. Рукопис свога „Утјешенија грјешним” Пејчиновић је предао штампару Теодосију, и он то дело сада штампа, препоручујући га „љубочитателима” као веома корисно дело, јер је писано разумљивим, народним језиком.

Испуњена вуковским мислима о значају употребе народног језика у књижевности, Теодосијева декларација истиче величину Пејчиновићевог дела, јер је оно писано тако „да ја читат и простиот народ." Сада се нико не може изговарати, вели Теодосије Синаитски: „не можеме да го знаеме оти ест по славјански или по росијски језик” написана књига, па је не разумеју. И уздигнутим гласом Теодосије штампар саопштава читаоцима: „Ево кључ что отворует средцето ваше; не кључ от злато или от сребро, до кључ от железо и челик, што да не се вие, оти среброто и златото ест меко и се вие скоро, но железото со челик не се вие! Кога да ест отворот сирјеч откључот от злато или от сребро, та да не може ковчегот сирјеч сердецго мое да отвори, что ми ест таков отвор (кључ)? Нека ест од челик и железо, та да отвори ковчегот, та да не ест од сребро и злато и да не може да отвори средцето на простиот человек”.

На овакав сликовит начин Теодосије Синаитски препоручује дело писано народним језиком, који је приказан као кључ искован од гвожђа и челика и може да отвори срце обичног човека, док златни и сребрени кључ представљају словенски и руски језик. Они су оба меки и не могу отворити срце обичног човека!

Док су прва два члана прве књижевне генерације у новој македонској књижевности - Крчовски и Пејчиновић - објавили више стотина страна написаних на лепо народном језику, при том не истичући посебно значај свог подухвата, - дотле трећи члан ове генерације, Теодосије Синаитски, на неколико страна свога предговора Пејчиновићевом „утјешенију грјешним”, својим манифестом у корист употребе народног живог језика у књижевности, јавља се као ватрени поборник Вукове реформе језика и правописа. 
Другу књижевну генерацију нове македонске књижевности представљају књижевни радници, који немају ничег заједничког са средњовековним погледима на живот и књижевност. Сви они колико их је, иако су стицајем околности у највећем броју случајева, навршили скоро све школе на грчком језику, у погодном часу вратили су се родној груди и народном језику, сваки од њих дајући и свој доринос новој македонској књижевности.

Веома интересантна личност из друге књижевне генерације у новој македонској књижевности је Јордан Хаџи Константинов-Џинот 18201882). Рођен у Велесу, пошто је завршио најнужније образовање да постане учитељ, он се касније развијао у неуморног борца за увођење народног језика у настави и у књижевности. Писао је доста: стихове, драмске текстове, путописе, научне прилоге: преводио са српског и грчког језика. Сви су му текстови на народном језику. Представник је романтичарског покрета у Македонији. Пише под знатним утицајем српске књижевности. Преводи Доситеја, Јована Стејића. Пише против употребе дебелог јера, назала, због чега је нападан у бугарској штампи и називан српским шпијуном. Осумњичен као такав, и уз то и као руски шпијун, морао је поднети велике муке по затворима и у изгнанству, у Малој Азији. Јордан Џинот је, добављајући из Србије разноврсну, и пре свега школску литературу за своју школу у Скопљу и за сеоске школе у скопском крају, дошао једног часа до уверења и да мења стари правопис, којим се служио. Сачувао је једно његово писмо упућено Читалаштву београдском (сада се чува у Архиву САНУ), писано у Скопљу 9. фебруара 1855. г., у коме између осталог пише:

„Молим Ваше правитељство Читалиштно ако има љубав и доблетворност да ми дадете една Србска граматика синтактическа и една логика, и една географија, и една свеска „Шумадинка”, - колко гроша ке будат с перво ке ви испратам... Молим за ово. Мислим хиљаду пути да ви заслужим. Ово искам за да преокренам правописоми на српски!" (X. Поленаковић, Кореспонденцијата на Јордан Хаџи Константинов-Џинот со Друштво српске словесности, Скопје, 1955. 10). Међутим, иако је у свој језик примио, преко литературе, велики број лексичких елемената и речничких обрта из српског језика, он је остао при старом правопису до краја свога живота.

Од браће Константина и Андреје Д. Петковић, двојице школованих македонских људи у Русији, који су касније ступили у руско држављанство и у руску дипломатску службу, сачувано је веома мало књижев- 
них текстова писаних на македонском језику: неколико песама, нешто превода са руског, чешког, словеначког. У Славистичкој ревији XVII-2, 1969. (број је посвећен академицима Коблару и Слоњаку) објавио сам „Два прилога за запознаването со препевите К. Д. Петковић од чешки на македонски јазик” (стр. 285-292). У закључку, између осталог рекао сам: „Треба да се обележи дека во свој препев - (ради се о макед. преводу делова Ханкиног 'Кралеводворског рукописа', 1825) а донекаде и во останатите-се чувствува духот на српскиот јазик, со кој К. Д. Петковић одлично се служел, пишувајки на него научни прилози и водејки кореспонденција". У погледу правописа сн се сасвим ослободио дебелог јера, местимично користећи Вуково ђ и ћ.

Српско ђ и ћ користио је и познати македонски препородитељ Димитрије Миладинов, један од двојице славних Миладиноваца, скупљача македонских народних умотворина и аутор првог крупног зборника македонских народних песама, штампаног у Загребу 1861. године. При увођењу материјала за свој Зборник млађи од Миладиноваца, Константин, следио је Вуков пример.

На весма симпатичан начин обавештава читаоце свог Речника од три језика. С. Македонски, арбанаски и турски, књига II, Београд 1875. године, самоуки лексикограф, историограф, фолклорист македонски Ђорђе Пуљевски о томе да му је било познато дело Вука Караџића и да га је следио у својој књижевној пракси. Говорећи о употреби слова $ъ, ~ \mathfrak{b}, \hbar$ - Пуљевски на овај оригиналан начин спомиње Вука: „Овие слова истолковал славни стихотвор Влкан Карацовски”. Пуљевски је име и презиме реформатора језика и правописа дао у облику свог, мијачког дијалекта, којим је писао, дакле Влкан место Вук и Караџовски место Караџић!

О раду групе македонских просветитеља на питању увођења македонског језика у школе и благослужење, у току шесте, седме и осме деценије прошлога века, написао је веома значајну књигу Блаже Конески: „Кон македонската преродба. Македонските учебници од 19. век”, Скопље, 1959. У књизи су простудирани уџбеници македонских просветитеља (Партенија Зографског, Кузмана Шапкарева, Ђорђа Пуљевског и др.), писани на македонском језику и радо употребљавани у македонским школама и у богослужењу кад је реч о литургијским текстовима.

У македонском друштву, крајем прошлог века све више је преовладавала Вукова реформа, тако да се почетком овог века јавља познати македонски научник и родољуб Крсте Мисирков који је у својој знаменитој књизи „За македониките работи” (О македонском питању), Софија,1903, спровео практично у живот Вукову реформу у погледу употребе народног језика и фонетског правописа. 
И овај Вуков пут следи се у СР Македонији до данашњег дана при чему је, на темељима централних македонских говора - и следећи пример Крста Мисиркова - изграђен македонски књижевни језик, којим се пише белетристика, научна литература, журналистика и др.

* Рад је претходно објављен у зборнику Научни састанак слависта у Вукове дане, 2, 137-142. 